Article

\title{
Design of ESR Slag for Remelting 9CrMoCoB Steel under Simple Protective Ar Gas
}

\author{
Leizhen Peng ${ }^{\circledR}$, Zhouhua Jiang * and Xin Geng \\ School of Metallurgy, Northeastern University, Shenyang 110819, China; neuwindqishi@163.com (L.P.); \\ gengx@smm.neu.edu.cn (X.G.) \\ * Correspondence: jiangzh63@163.com; Tel.: +86-24-8369-1689
}

Received: 21 October 2019; Accepted: 28 November 2019; Published: 2 December 2019

\begin{abstract}
Thermodynamic calculations by using Factsage 7.3 and simple protective gas electroslag remelting (ESR) experiments were conducted to design the appropriate ESR slag for remelting the qualified $9 \mathrm{CrMoCoB}$ ingot. First, the proper basic slag was determined based on the phase diagram of $\mathrm{CaF}_{2}-\mathrm{CaO}-\mathrm{Al}_{2} \mathrm{O}_{3}-x \% \mathrm{MgO}$ calculated using Factsage 7.3. Second, equilibrium reactions between $9 \mathrm{CrMoCoB}$ and the basic slag containing varied $\mathrm{SiO}_{2}$, and $\mathrm{B}_{2} \mathrm{O}_{3}$ contents were calculated to study the effects of $\mathrm{B}_{2} \mathrm{O}_{3}$ and $\mathrm{SiO}_{2}$ on $\mathrm{B}, \mathrm{Si}$, and $\mathrm{Al}$ contents in steel. Then, equilibrium reaction experiments were conducted to validate the calculated results. Finally, the appropriate slags were attained and the simple protective Ar gas ESR experiments were conducted to make a verification. Results showed that the liquid phase region of the slag of $\mathrm{CaF}_{2}-\mathrm{CaO}-\mathrm{Al}_{2} \mathrm{O}_{3}-x \% \mathrm{MgO}$ at $1300-1400{ }^{\circ} \mathrm{C}$ increased first, then decreased with the $\mathrm{MgO}$ addition. With the $\mathrm{B}_{2} \mathrm{O}_{3}$ content increasing, the boron content increased, while the $\mathrm{Si}, \mathrm{Al}$ contents decreased, and at a given $\mathrm{B}_{2} \mathrm{O}_{3}$ addition, the $\mathrm{B}$ and $\mathrm{Al}$ contents decreased with the $\mathrm{SiO}_{2}$ content increasing, whereas the $\mathrm{Si}$ content increased. The appropriate slags for simple protective gas ESR remelting $9 \mathrm{CrMoCoB}$ were $55 \% \mathrm{CaF}_{2}-20 \% \mathrm{CaO}-3 \% \mathrm{MgO}-22 \% \mathrm{Al}_{2} \mathrm{O}_{3}-2 \% \mathrm{SiO}_{2}-1.3 \% \mathrm{~B}_{2} \mathrm{O}_{3}$ and $55 \% \mathrm{CaF}_{2}-20 \% \mathrm{CaO}-3 \% \mathrm{MgO}-22 \% \mathrm{Al}_{2} \mathrm{O}_{3}-3 \% \mathrm{SiO}_{2}-1.7 \% \mathrm{~B}_{2} \mathrm{O}_{3}$.
\end{abstract}

Keywords: 9CrMoCoB; Factsage; ESR; slag; qualified ingot

\section{Introduction}

Fossil fuel power plants currently supply more than $60 \%$ of the world's electricity production, and they remain the most important sources of electricity in the near future [1,2]. To overcome the challenges of great energy consumption and high pollution associated with the fossil fuel power plants, improving the efficiency of thermal power plants by increasing the temperature and pressure of the working stream has been pursued for many decades. $9 \mathrm{CrMoCoB}$ (COST-FB2) was developed in the framework of European COST program for the production of large-scale rotor forging with good creep property at $625^{\circ} \mathrm{C}$ and $32 \mathrm{MPa}$ pressure. Under these ultra-supercritical conditions, the efficiency of thermal power plants can increase by $\sim 5 \%$, and $\mathrm{CO}_{2}$ emissions can reduce by $\sim 10 \%$, compared with the world average at present $[3,4]$.

The rotor is one of the most important components of steam turbines and its working condition is severe. Given that, high metallurgical quality is required. To reduce the loss of the chemically active and main reinforced elements B (the content rang of B is narrow: 0.008-0.011\%) and produce the qualified ingot, many turbine manufacturers have adopted the protective Ar gas ESR $[5,6]$ to produce the $9 \mathrm{CrMoCoB}$ ingot. However, the protective gas ESR furnance is costly and during the protective Ar gas ESR process, the soft arcing caused by the ionization of the argon has a bad effect on interior and exterior quality of the ingot [7]. To improve the ingot quality and reduce manufacturing cost, it is necessary to develop the proper slag for remelting the qualified ingot under the simple protective Ar gas. 
The molten slag has a great influence on the metallurgical quality of the ingot during ESR process [8,9]. Previous researchers have extensively studied the effects of slag compositions and properties on the quality of the ingot. Pateisky [10], Medina [11], and Carmona [12] mainly researched the effects of slag compositions on the ingot contents during ESR process, and pointed out that to reduce the loss of the chemically active element, adding the components involved in the redox reaction into the molten slag is an effective method [13]. During the ESR process, if the redox reactions between the slag and steel are in equilibrium state, the contents of the chemically active alloyed elements in the ingot may keep steady.

Factsage is a useful tool for thermodynamic modeling of high-temperature metallurgical processes. Many researchers have adopted Factsage to simulate different ironmaking processes $[14,15]$ and calculate the chemical physical properties of the slags [16]. In this work, the effects of the slag with varied $\mathrm{SiO}_{2}$ and $\mathrm{B}_{2} \mathrm{O}_{3}$ contents on the $\mathrm{B}, \mathrm{Si}$, and $\mathrm{Al}$ contents in steel were studied via Factsage 7.3 calculations. Based on the calculated results, four slags were designed and the equilibrium reaction experiments were conducted to validate the calculated results. Then, the appropriate slags were attained by comprehensive analysis the calculated and experimental results, and the laboratory-scale simple protective gas ESR experiments were carried out to make a verification. The results of this work will provide some reference and guidance for the industrial production of the qualified $9 \mathrm{CrMoCoB}$ ingot using the simple protective Ar gas ESR.

\section{Experiments and Calculations}

The ESR slag compositions mainly include $\mathrm{CaF}_{2}, \mathrm{CaO}$, and $\mathrm{Al}_{2} \mathrm{O}_{3}$. A small amount of $\mathrm{MgO}$ is needed for reducing the electrical conductivity [17] and surface tension [18] of the molten slag.

The $\mathrm{B}(0.008-0.011 \%)$ and $\mathrm{Al}(0.003 \%)$ contents in the $9 \mathrm{CrMoCoB}$ are low, the $\mathrm{Si}(0.05 \%)$ content is relatively high, whereas the $\mathrm{Al}_{2} \mathrm{O}_{3}$ content in the ESR slag is high and the $\mathrm{SiO}_{2}$ content is relatively low. The components involved in the redox reactions between the molten slag and steel are not in the standard state, and the $\Delta \mathrm{G}$ of the reactions are related to the activities of the components. Thus, during ESR remelting $9 \mathrm{CrMoCoB}$, reactions (1) and (2) may occur between molten slag and steel:

$$
\begin{gathered}
3 \mathrm{Si}+2 \mathrm{Al}_{2} \mathrm{O}_{3}=4 \mathrm{Al}+3 \mathrm{SiO}_{2} \\
3 \mathrm{Si}+2 \mathrm{~B}_{2} \mathrm{O}_{3}=4 \mathrm{~B}+3 \mathrm{SiO}_{2}
\end{gathered}
$$

To reduce the loss of main reinforced element $\mathrm{B}$ and the accumulation of deleterious element $\mathrm{Al}, \mathrm{SiO}_{2}$ and $\mathrm{B}_{2} \mathrm{O}_{3}$ should be added into the slag to decrease the degree of slag-metal reactions [19]. To study the effects of $\mathrm{B}_{2} \mathrm{O}_{3}$ and $\mathrm{SiO}_{2}$ addition into the molten slag on the $\mathrm{B}, \mathrm{Si}$, and $\mathrm{Al}$ contents in the steel, the compositions of the basic slag of $\mathrm{CaF}_{2}-\mathrm{CaO}-\mathrm{Al}_{2} \mathrm{O}_{3}-\mathrm{MgO}$ should be determined first.

\subsection{Determining the Basic Slag}

The liquidus temperature of $9 \mathrm{CrMoCoB}$ was $1498^{\circ} \mathrm{C}$ calculated by using Thermo-Calc 6.4 (database TCFE7). The liquid phase region of $\mathrm{CaF}_{2}-\mathrm{CaO}-\mathrm{Al}_{2} \mathrm{O}_{3}$ with varied $\mathrm{MgO}$ addition at $1250-1400{ }^{\circ} \mathrm{C}$ with a $50{ }^{\circ} \mathrm{C}$ interval was calculated by using the Phase Diagram mode in Factsage 7.3 (database FToxid), results shown in Figure 1.

For the sake of reducing the energy consumption and the good surface quality of the ingot, the liquidus temperature of the molten slag should be lower than the liquidus temperature of the electrode by $100-200{ }^{\circ} \mathrm{C}$ [20], the proper liquidus temperature of the molten slag was $1300-1400{ }^{\circ} \mathrm{C}$. In Figure 1 , the area of the liquid phase region at $1300-1400{ }^{\circ} \mathrm{C}$ increased first, then, decreased, with the $\mathrm{MgO}$ addition. The liquid phase regions at $1300-1400{ }^{\circ} \mathrm{C}$ of the $\mathrm{CaF}_{2}-\mathrm{CaO}-\mathrm{Al}_{2} \mathrm{O}_{3}$ with $2 \% \mathrm{MgO}$ or $3 \% \mathrm{MgO}$ addition were both suitable for ESR process, and $\mathrm{MgO}$ addition can reduce the electrical conductivity and surface tension of the molten slag. Thus, in this work, $3 \% \mathrm{MgO}$ addition was chosen. 
The isothermal section phase diagram of $\mathrm{CaF}_{2}-\mathrm{CaO}-\mathrm{Al}_{2} \mathrm{O}_{3}-3 \% \mathrm{MgO}$ at $1200-1400{ }^{\circ} \mathrm{C}$ were calculated using the Phase Diagram mode in the Factsage 7.3 (database FToxid) and the calculated result is shown in Figure 2.

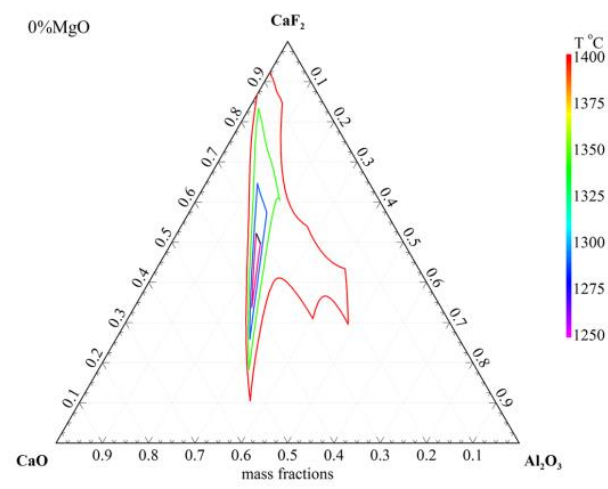

(a)

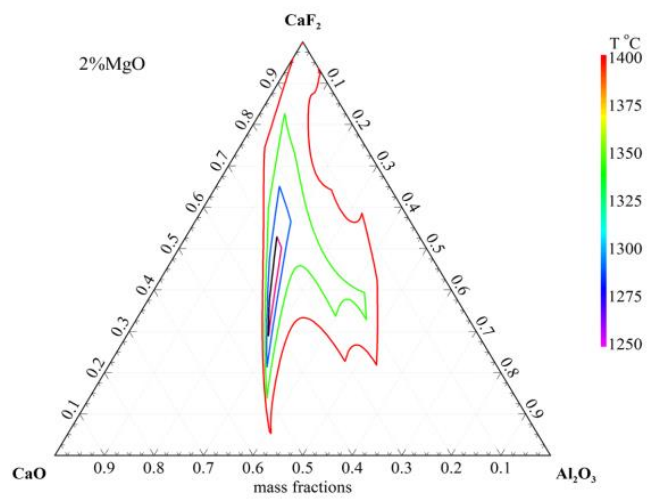

(c)

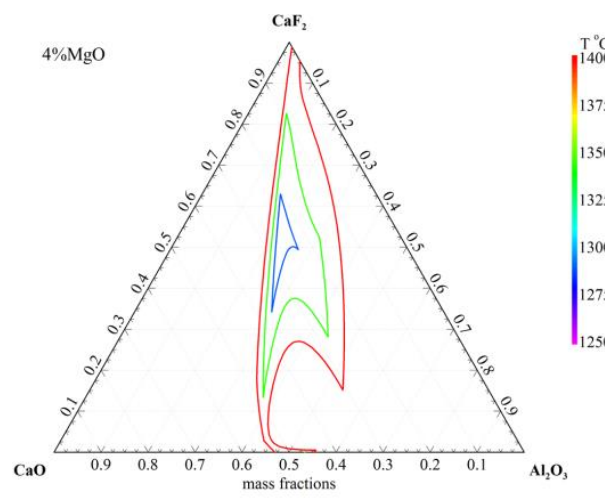

(e)

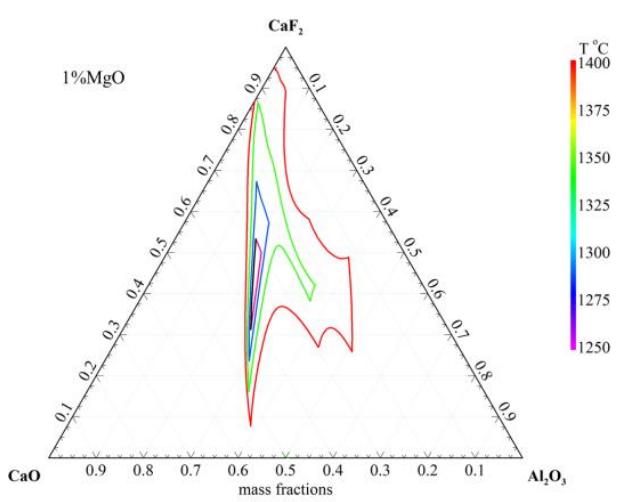

(b)

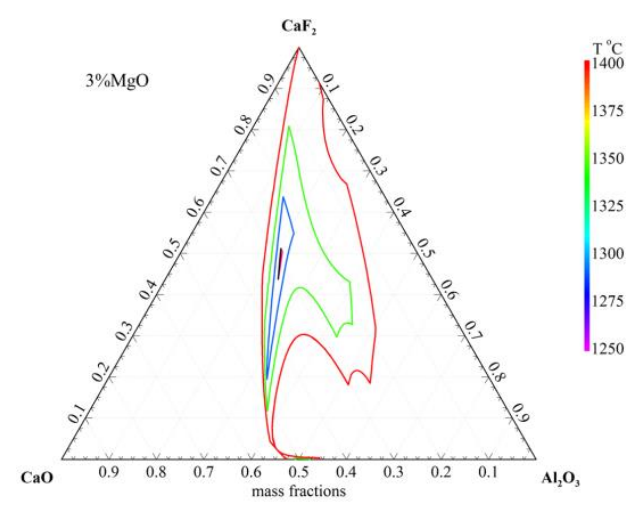

(d)

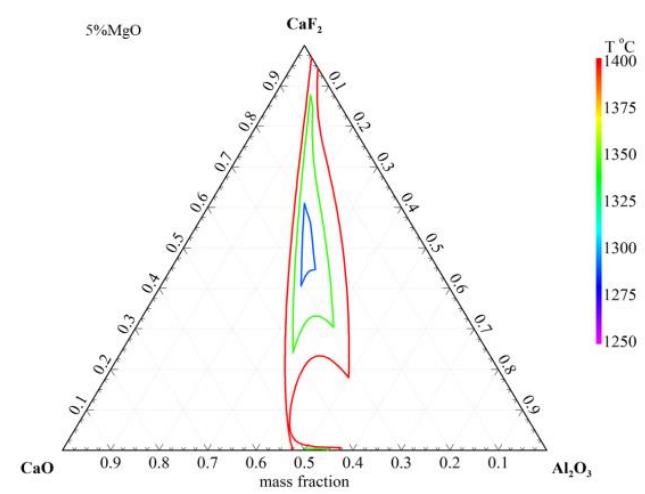

(f)

Figure 1. The liquid phase region of the $\mathrm{CaF}_{2}-\mathrm{CaO}-\mathrm{Al}_{2} \mathrm{O}_{3}-x \% \mathrm{MgO}$ at temperature of $1250-1400{ }^{\circ} \mathrm{C}$ with $50{ }^{\circ} \mathrm{C}$ interval: (a) $0 \% \mathrm{MgO}$; (b) $1 \% \mathrm{MgO}$; (c) $2 \% \mathrm{MgO}$; (d) $3 \% \mathrm{MgO}$; (e) $4 \% \mathrm{MgO}$; (f) $5 \% \mathrm{MgO}$.

The $\mathrm{CaF}_{2}$ content in ESR slag is usually $~ 50 \%$ to attain good fluidity. The slag compositions around the red dotted line $\left(\mathrm{wt}\left(\mathrm{Al}_{2} \mathrm{O}_{3}\right) / \mathrm{wt}(\mathrm{CaO})=1\right.$, shown in Figure 2$)$ were usually chosen as the proper ESR slag for the relatively low liquidus temperature and stable chemical property [21]. During ESR process, the reaction between $\mathrm{CaF}_{2}$ and $\mathrm{CaO}$ shown below led to the accumulation of $\mathrm{CaO}$ and loss of $\mathrm{Al}_{2} \mathrm{O}_{3}$.

$$
3 \mathrm{CaF}_{2}+\mathrm{Al}_{2} \mathrm{O}_{3}=2 \mathrm{AlF}_{3}+3 \mathrm{CaO}
$$


To keep the physical properties and the operation stable during the ESR process, $w t\left(\mathrm{Al}_{2} \mathrm{O}_{3}\right) / \mathrm{wt}$ $(\mathrm{CaO})$ ratio should be slightly greater than 1 . In this work, the designed proper basic slag was $55 \% \mathrm{CaF}_{2}-20 \% \mathrm{CaO}-22 \% \mathrm{Al}_{2} \mathrm{O}_{3}-3 \% \mathrm{MgO}$ shown in Figure 2 (the red plot).

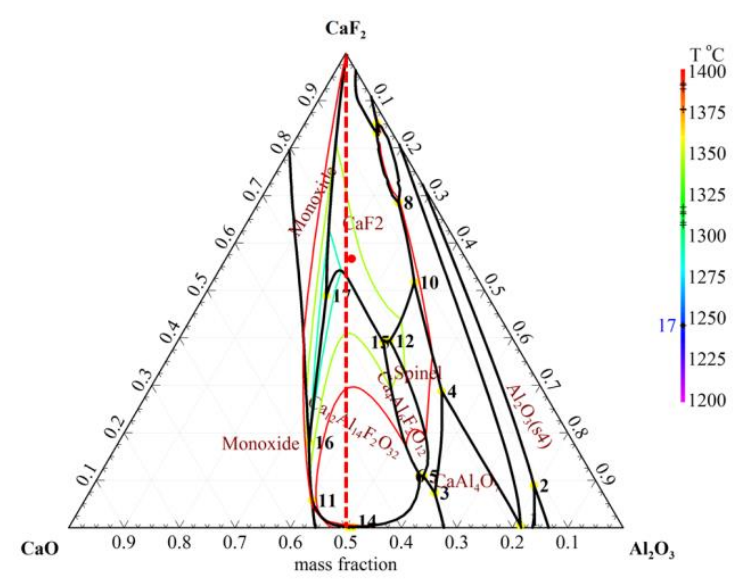

Figure 2. The $1200-1400{ }^{\circ} \mathrm{C}$ isothermal section phase diagram of $\mathrm{CaF}_{2}-\mathrm{CaO}-\mathrm{Al}_{2} \mathrm{O}_{3}-3 \% \mathrm{MgO}$.

\subsection{Factsage Calculations and the Equilibrium Reaction Experiments}

\subsubsection{Factsage Calculation}

The equilibrium reactions between the molten $9 \mathrm{CrMoCoB}$ steel and the molten slag of $55 \% \mathrm{CaF}_{2}-20 \% \mathrm{CaO}-22 \% \mathrm{Al}_{2} \mathrm{O}_{3}-3 \% \mathrm{MgO}-x \% \mathrm{SiO}_{2}-y \% \mathrm{~B}_{2} \mathrm{O}_{3}$ were calculated by using Equilib mode in Factsage 7.3 (database FToxid, FTmisc, and FactPS) to figure out the effects of $\mathrm{B}_{2} \mathrm{O}_{3}$ and $\mathrm{SiO}_{2}$ contents in the slag on the $\mathrm{B}, \mathrm{Si}$, and $\mathrm{Al}$ contents in steel. The calculated conditions follow; mass ratio of the slag with steel was 1:6, temperature was $1823 \mathrm{~K}\left(1550^{\circ} \mathrm{C}\right)$, and atmosphere was $1 \mathrm{~mol}$ Ar with $0.0002 \mathrm{~mol}$ $\mathrm{O}_{2}$ under $0.1 \mathrm{MPa}$ (volume fraction of $\mathrm{O}_{2}$ was $0.2 \%$ ).

Based on the calculated results, four slags were designed. To verify the calculated results, the equilibrium reaction experiments between the designed slags and $9 \mathrm{CrMoCoB}$ steel were conducted using the four designed slags.

\subsubsection{Equilibrium Reaction Experiments}

The reagent-grade powders of wt $(\mathrm{CaO}) \geq 97 \%$, wt $(\mathrm{MgO}) \geq 98 \%$, wt $\left(\mathrm{CaF}_{2}\right) \geq 98.5 \%$, wt $\left(\mathrm{Al}_{2} \mathrm{O}_{3}\right)$ $\geq 98.5 \%$, wt $\left(\mathrm{SiO}_{2}\right) \geq 98.5 \%$ and wt $\left(\mathrm{B}_{2} \mathrm{O}_{3}\right) \geq 98 \%$ were used to pre-melt the slags. The powders were mixed completely, then put in a graphite crucible lined with a $0.2 \mathrm{~mm}$-thick molybdenum film and heated in the $\mathrm{MoSi}_{2}$ furnace shown in Figure 3. During the experiment, the temperature was continuously measured using a B-type thermocouple, and the final temperature was $1723 \mathrm{~K}\left(1450{ }^{\circ} \mathrm{C}\right)$. For composition homogeneity, the slags were held at $1723 \mathrm{~K}$ for $50 \mathrm{~min}$ and then furnace-cooled to room temperature. The crushed pre-melted slags were subjected to chemical analysis. The $\mathrm{B}_{2} \mathrm{O}_{3}$ and $\mathrm{SiO}_{2}$ contents were analyzed in the national analysis center for iron and steel (CISRI) using the method of ICP-AES, and the other main chemical compositions of the slags were analyzed using the X-ray fluorescence spectroscopy (Rigaku ZSX Primus II, Tokyo, Japan).

Each equilibrium reaction experiment was conducted with $600 \mathrm{~g} 9 \mathrm{CrMoCoB}$ steel (remelted in Electrometallurgy Laboratory of Northeastern University using the $30 \mathrm{~kg}$ vacuum induction furnace and contents shown in Table 1) and 100 g pre-melted slag. The experiments were conducted in a magnesium oxide crucible lined with a $0.2-\mathrm{mm}$-thick molybdenum film at the isothermal zone of the $\mathrm{MoSi}_{2}$ furnace shown in Figure 3 . The furnace was heated to preset $1823 \mathrm{~K}\left(1550^{\circ} \mathrm{C}\right)$ at a rate of $8 \mathrm{~K} / \mathrm{min}$. During the experiments, pure argon began to blow from gas tube into the furnace as the protecting gas when the temperature was above $673 \mathrm{~K}\left(400^{\circ} \mathrm{C}\right)$. The bottom argon gas flow rate was $3 \mathrm{NL} / \mathrm{min}$, and 
the top argon gas flow rate was $6 \mathrm{NL} / \mathrm{min}$, the concentration of $\mathrm{O}_{2}$ in the furnace atmosphere ranged from 0.2 to $0.3 \%$ (volume fraction).

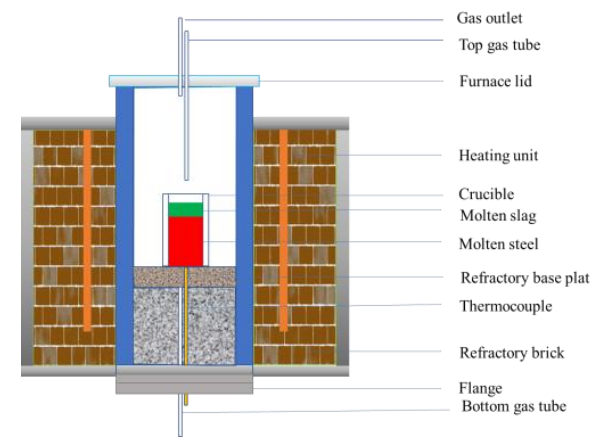

Figure 3. Schematic diagram of experimental resistance furnace.

Table 1. The compositions of $9 \mathrm{CrMoCoB}$ steel wt. $\%$.

\begin{tabular}{cccccccccccccc}
\hline Content & $\mathbf{C}$ & $\mathbf{S i}$ & $\mathbf{M n}$ & $\mathbf{B}$ & $\mathbf{A l}$ & $\mathbf{C r}$ & $\mathbf{M o}$ & $\mathbf{C o}$ & $\mathbf{O}$ & $\mathbf{N i}$ & $\mathbf{N b}$ & $\mathbf{N}$ & $\mathbf{F e}$ \\
\hline EXP. & 0.136 & 0.0495 & 0.34 & 0.010 & 0.003 & 9.36 & 1.48 & 1.28 & 0.0028 & 0.16 & 0.06 & 0.021 & Bal. \\
Min. & 0.110 & - & 0.28 & 0.008 & - & 9.05 & 1.40 & 1.15 & - & 0.10 & 0.04 & 0.015 & \\
Max. & 0.150 & 0.1000 & 0.42 & 0.011 & 0.01 & 9.60 & 1.60 & 1.45 & 0.0035 & 0.25 & 0.07 & 0.030 & \\
Goal & 0.120 & 0.0500 & 0.35 & 0.010 & 0.007 & 9.30 & 1.50 & 1.30 & - & 0.15 & 0.06 & 0.020 & \\
\hline
\end{tabular}

When the temperature reached $1823 \mathrm{~K}$, the -0\# steel sample was taken as the initial steel chemical composition using a quartz tube. One-hundred grams of pre-melted slag was then put into the crucible divided into five times, and to avoid the slag to be out of the crucible, the crushed pre-melted slag was wrapped in paper. To determine the equilibrium time of the reactions, it is necessary to take samples at different reaction times. The reaction time began to calculate after the slag was added (the time for adding the slag was as short as $50 \mathrm{~s}$, so the time was negligible). Subsequently, the steel samples were taken at 20, 40, and $60 \mathrm{~min}$ and labeled as $-1 \#,-2 \#$, and $-3 \#$, respectively. To extract the steel sample, the furnace lid should be lifted away from the furnace first, then the quartz tube was put into the furnace to extract the steel sample from the top of the furnace. The extracted steel samples were cooled in water immediately.

\subsection{Laboratory-Scale ESR Experiments}

\subsubsection{The Viscosity of the Proper Slags}

The proper slags were obtained based on the comprehensive analysis the experimental and calculated results. The viscosity of the proper slags was calculated by using Viscosity mode in Factsage 7.3. In the Viscosity mode in Factsage, the molten slag was assumed to be the single liquid phase at any temperature. The actual viscosity (viscosity of slag containing solid precipitations) was calculated using the equation of Einstein-Roscoe [22] shown in Equation (4).

$$
\eta=\eta_{0} *(1-\alpha f)^{-n}
$$

Here, $\eta$ is the actual viscosity of the melt, $\eta_{0}$ is the calculated viscosity by Factsage 7.3, $\alpha$ and $n$ are constants, and $f$ is the volume fraction of the solid particles in the melt.

Roscoe suggested $\alpha$ and $n$ to be 1.35 and 2.5 [23], respectively, by assuming that solid precipitation was spherical particles with a uniform size. To simplify the calculation, the mass fraction of the crystalline phase was instead of the volume fraction [24]. The mass of the precipitates during the solidification were calculated by using the Equilib mode in Factsage 7.3. 


\subsubsection{Laboratory-Scale Simple Protective Gas ESR Experiments}

To produce the qualified ingot, the viscosity of the molten slag should change slightly with the temperature changing. Based on the analysis of the calculated viscosity of the slags, the appropriate slags were obtained. The laboratory-scale ESR experiments were conducted to make a verification. The compositions of the electrodes are shown in Table 2, and the detailed ESR operating parameters are shown in Table 3. The ESR experiments were conducted under the simple protective gas, and the schematic diagram of the experimental set-up was shown in Figure 4. During the remelting process, pure Ar was blown at $24 \mathrm{NL} / \mathrm{min}$. An oxygen concentration sensor was used to detect the concentration of $\mathrm{O}_{2}$ above the molten slag to adjust the concentration of $\mathrm{O}_{2}$ at $0.5 \%$ (volume fraction, the lower limit of the furnace).

Table 2. The compositions of electrode wt.\%.

\begin{tabular}{ccccccccccccc}
\hline $\mathbf{C}$ & $\mathbf{S i}$ & $\mathbf{M n}$ & $\mathbf{B}$ & $\mathbf{A l}$ & $\mathbf{C r}$ & $\mathbf{M o}$ & $\mathbf{C o}$ & $\mathbf{O}$ & $\mathbf{N i}$ & $\mathbf{N b}$ & $\mathbf{N}$ & $\mathbf{F e}$ \\
\hline 0.132 & 0.048 & 0.348 & 0.0098 & 0.004 & 9.49 & 1.54 & 1.27 & 0.0028 & 0.15 & 0.058 & 0.024 & Bal. \\
\hline
\end{tabular}

Table 3. The detailed operating parameters of the laboratory-scale ESR.

\begin{tabular}{ccc}
\hline \multirow{2}{*}{ ESR Melting } & Furnace & Simple Protective Furnace \\
\cline { 2 - 3 } & Remelting speed $/ \mathbf{k g} / \mathbf{m i n}$ & $\mathbf{1 . 2}$ \\
\hline Mould & Diameter $/ \mathrm{mm}$ & 125 \\
Electrode & Diameter $/ \mathrm{mm}$ & 75 \\
Slag & Weight $/ \mathrm{kg}$ & 3.2 \\
\hline
\end{tabular}

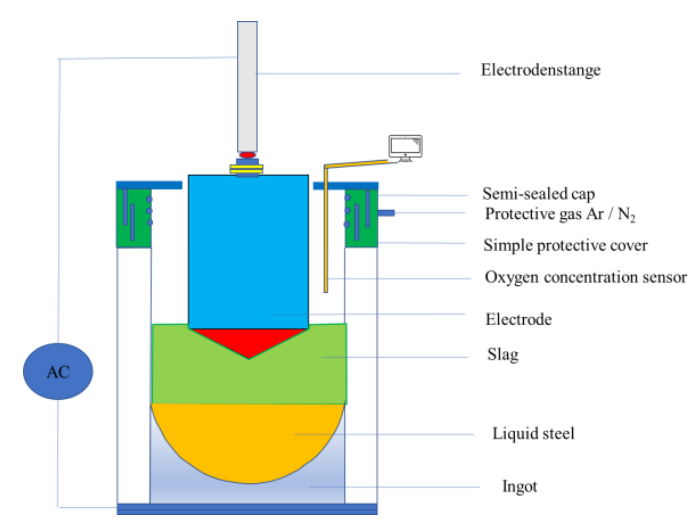

Figure 4. The schematic diagram of the experimental laboratory-scale ESR furnaces.

To analyze the vertical distributions of $\mathrm{B}, \mathrm{Si}$, and $\mathrm{Al}$ contents in the ESR ingot from bottom to top, the ingot was vertically cut into two parts through its center and the procedures were shown in Figure 5 . The analysis mainly focused on vertical changes of $\mathrm{B}, \mathrm{Si}$, and $\mathrm{Al}$ contents from bottom to top of the ingot.

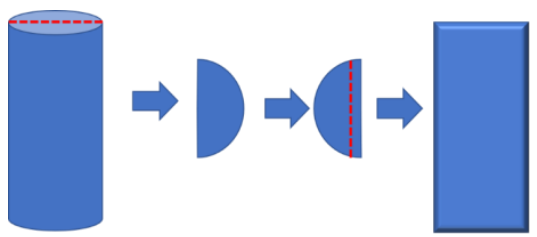

Figure 5. The axial anatomy of ingot. 


\subsection{Analysis}

An optical emission spectrometer (ARL 4460, Waltham, MA, USA) was used to detect the main alloying elements in the steel samples. The alloyed elements B, Al, and Si contents were analyzed in the national analysis center for iron and steel (CISRI) using the method of ICP-AES.

\section{Results and Discussions}

\subsection{Calculated Results by Using Factsage 7.3}

The calculated results of the equilibrium reactions between molten slag of $55 \% \mathrm{CaF}_{2}-20 \% \mathrm{CaO}-$ $3 \% \mathrm{MgO}-22 \% \mathrm{Al}_{2} \mathrm{O}_{3}-x \% \mathrm{SiO}_{2}-y \% \mathrm{~B}_{2} \mathrm{O}_{3}(x \leq 3, y \leq 3)$ and $9 \mathrm{CrMoCoB}$ using Factsage 7.3 are shown in Figure 6. In Figure 6, the $\mathrm{B}, \mathrm{Si}$, and $\mathrm{Al}$ contents were the equilibrium contents in the molten steel after reaction with the molten slag with varied $\mathrm{SiO}_{2}$ and $\mathrm{B}_{2} \mathrm{O}_{3}$ contents.

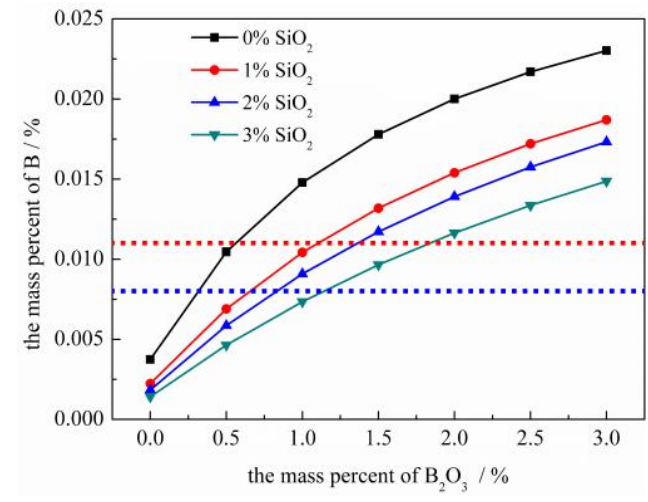

(a)

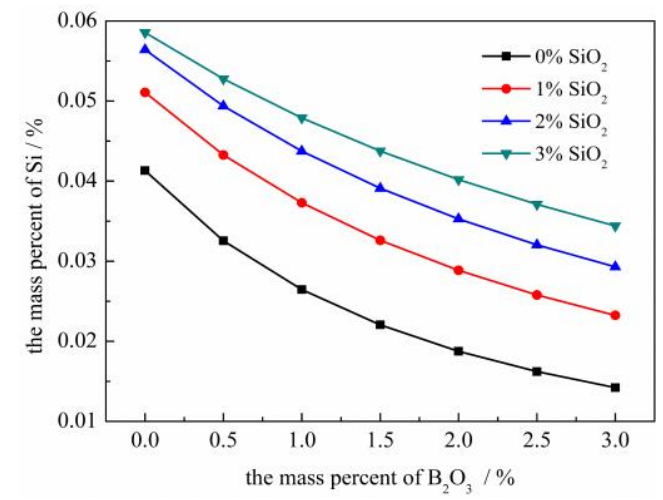

(b)

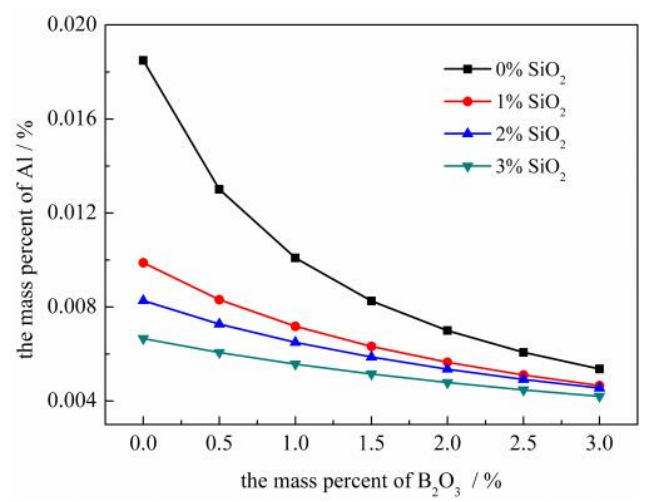

(c)

Figure 6. The effect of varied $\mathrm{B}_{2} \mathrm{O}_{3}$ and $\mathrm{SiO}_{2}$ addition on the $\mathrm{B}, \mathrm{Si}$, and $\mathrm{Al}$ contents: (a) B content; (b) $\mathrm{Si}$ content; (c) Al content.

As shown in Figure 6, the boron content increased, while the $\mathrm{Si}, \mathrm{Al}$ contents decreased simultaneously with the increasing $\mathrm{B}_{2} \mathrm{O}_{3}$ addition. Further, at a given $\mathrm{B}_{2} \mathrm{O}_{3}$ addition, the $\mathrm{B}, \mathrm{Al}$ contents decreased, while the $\mathrm{Si}$ content increased concurrently with the increasing $\mathrm{SiO}_{2}$ addition. The range of the B content was also shown in Figure 6. The red dotted line was the upper limit of the $\mathrm{B}$ content range $(0.011 \%)$, the blue dotted line was the lower limit of the $\mathrm{B}$ content range $(0.008 \%)$. To verify the calculated results, the four designed slags are shown in Table 4 . The compositions of the pre-melted slags are also shown in Table 4. 
Table 4. The compositions of the new designed slag wt. $\%$.

\begin{tabular}{ccccccccccccc}
\hline \multicolumn{1}{c}{ Before Pre-Melted } & \multicolumn{5}{c}{ After Pre-Melted } \\
\hline NO. & $\mathbf{C a F}_{\mathbf{2}}$ & $\mathbf{C a O}$ & $\mathbf{A l}_{\mathbf{2}} \mathbf{O}_{\mathbf{3}}$ & $\mathbf{M g O}$ & $\mathbf{S i O}_{\mathbf{2}}$ & $\mathbf{B}_{\mathbf{2}} \mathbf{O}_{\mathbf{3}}$ & $\mathbf{C a F}_{\mathbf{2}}$ & $\mathbf{C a O}$ & $\mathbf{A l}_{\mathbf{2}} \mathbf{O}_{\mathbf{3}}$ & $\mathbf{M g O}$ & $\mathbf{S i O}_{\mathbf{2}}$ & $\mathbf{B}_{\mathbf{2}} \mathbf{O}_{\mathbf{3}}$ \\
\hline $1 \#$ & 55 & 20 & 22 & 3.0 & 0.0 & 0.5 & 52.90 & 21.15 & 21.71 & 3.08 & 0.18 & 0.47 \\
$2 \#$ & 55 & 20 & 22 & 3.0 & 1.0 & 1.0 & 52.60 & 20.56 & 21.46 & 3.03 & 1.16 & 0.96 \\
$3 \#$ & 55 & 20 & 22 & 3.0 & 2.0 & 1.3 & 51.96 & 20.22 & 21.19 & 2.98 & 2.11 & 1.24 \\
$4 \#$ & 55 & 20 & 22 & 3.0 & 3.0 & 1.7 & 51.32 & 20.03 & 20.91 & 2.95 & 3.05 & 1.61 \\
\hline
\end{tabular}

\subsection{Results of Equilibrium Reaction Experiments}

The changes in $\mathrm{B}, \mathrm{Si}$, and $\mathrm{Al}$ contents in the steel versus time of the four equilibrium reaction experiments using the designed slags are shown in Figure 7. The B, Si, and Al contents at different reaction time were not the equilibrium contents in the molten steel. Thus, the $\mathrm{Al}$ content changing with time behavior was not the same with the behavior of $\mathrm{Al}$ changing with the $\mathrm{B}_{2} \mathrm{O}_{3}$ addition shown in Figure 6.

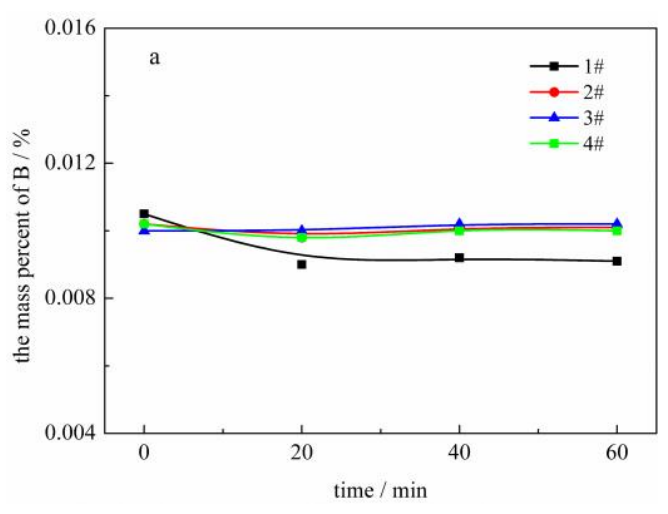

(a)

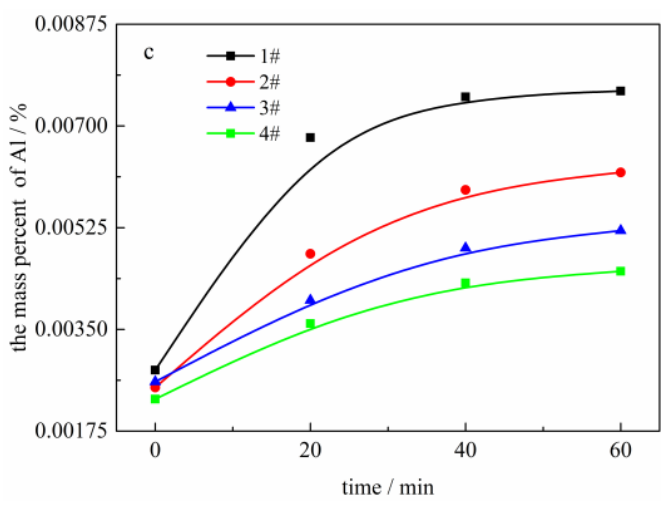

(c)

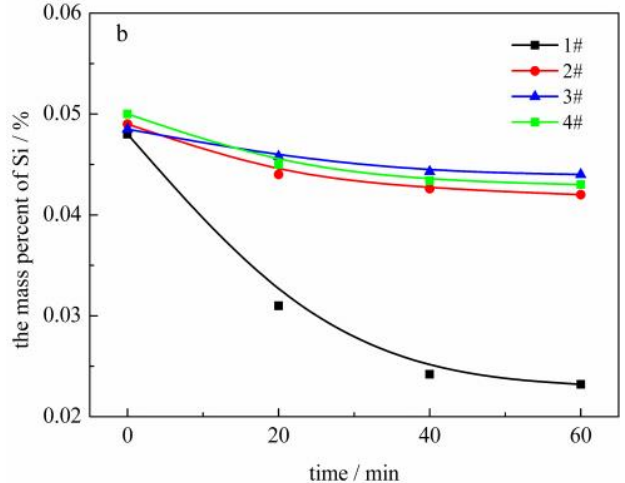

(b)

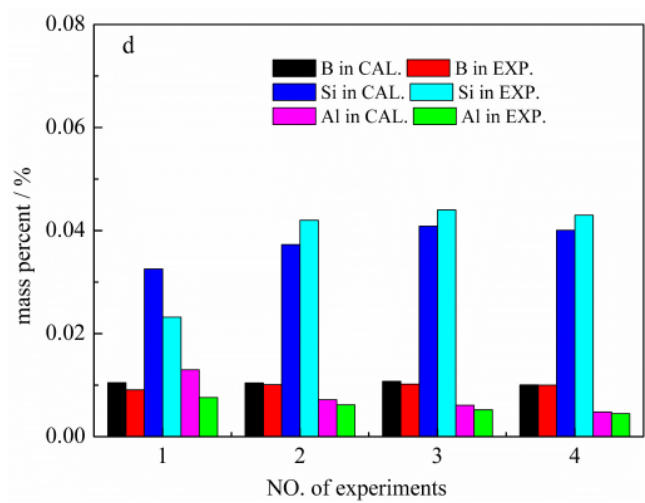

(d)

Figure 7. The changes in $\mathrm{B}, \mathrm{Si}$, and $\mathrm{Al}$ contents with reaction time and contrast between the calculated $\mathrm{B}, \mathrm{Si}$, and $\mathrm{Al}$ contents with the experimental equilibrium $\mathrm{B}, \mathrm{Si}$, and $\mathrm{Al}$ contents: (a) $\mathrm{B}$; (b) $\mathrm{Si}$; (c), $\mathrm{Al}$; (d) contrast results.

As seen in Figure 7a, the boron content in the 2\# 4\# heats kept steady, whereas in the 1\# heat, the boron content decreased slightly at first, then kept steady soon. In Figure 7b, the Si content in $1 \#$ heat decreased distinctly, and reached stable after $40 \mathrm{~min}$, whereas in 2\# 4\# heats, the Si content decreased slightly, then kept steady soon. In Figure $7 \mathrm{c}$, the $\mathrm{Al}$ content increased with the reaction time, and the $\mathrm{Al}$ content reached stable after $40 \mathrm{~min}$ in the four heats. In the equilibrium reaction experiments, the reaction between $\mathrm{Si}$ and $\mathrm{Al}_{2} \mathrm{O}_{3}$ was not in equilibrium state, the $\mathrm{Al}$ content changed 
compared to the initial content. These results indicated that the reactions between slag and steel were in equilibrium state at $60 \mathrm{~min}$.

The equilibrium $\mathrm{B}, \mathrm{Si}$, and $\mathrm{Al}$ contents calculated by using Factsage were compared with the experimental equilibrium $\mathrm{B}, \mathrm{Si}$, and $\mathrm{Al}$ contents at $60 \mathrm{~min}$, and the results are shown in Figure $7 \mathrm{~d}$.

In Figure $7 \mathrm{~d}$, the calculated equilibrium $\mathrm{B}, \mathrm{Si}$, and $\mathrm{Al}$ contents were close to the experimental results. In the 2\# heat, the $\mathrm{B}$ content kept steady, and the Si content decreased slightly with the reaction time. Thus, the reaction between $\mathrm{Si}$ and $\mathrm{B}_{2} \mathrm{O}_{3}$ was in equilibrium state during the experiments. The $\mathrm{Al}$ content increased with the reaction time, but the consumption of $\mathrm{Si}$ caused by the reaction between $\mathrm{Si}$ and $\mathrm{Al}_{2} \mathrm{O}_{3}$ was very limited, so the loss of $\mathrm{Si}$ was not only caused by the reaction between $\mathrm{Si}$ and $\mathrm{Al}_{2} \mathrm{O}_{3}$. The equilibrium reaction experiment was not conducted in the fully sealed furnace, atmospheric oxygen can enter in the furnace, and the reaction between $\mathrm{Si}$ and $\mathrm{FeO}$ (oxidation products during the melting process) occurred led to the loss of $\mathrm{Si}$. With the $\mathrm{SiO}_{2}$ content in the slag increasing, the reaction between the $\mathrm{Si}$ and $\mathrm{FeO}$ was annihilated and the deviation of $\mathrm{Si}$ content between the experimental and calculated results became small. Thus, in the 1\# heat, the Si content in the experimental results was a little less than the Si content in the calculated results can be understandable. On the whole, the calculated results by Factsage were similar to the experimental results.

From the above analysis, the 1\# slag was not suitable for ESR remelting $9 \mathrm{CrMoCoB}$ steel, for the equilibrium $\mathrm{Al}$ content $(0.0076 \%)$ was close to the upper limit $(0.01 \%)$, and the loss of Si content was great in the equilibrium reaction experiment using the $1 \#$ slag. While in the equilibrium reaction experiments using the $2 \# \sim 4 \#$ slags, the loss of the equilibrium content of $\mathrm{Si}$ and the increasement of the equilibrium content of $\mathrm{Al}$ was slight, and the equilibrium $\mathrm{B}, \mathrm{Si}$, and $\mathrm{Al}$ contents kept steady soon. The redox reactions between the molten slag and steel were in quasi-equilibrium state, thus the proper slag for ESR remelting 9CrMoCoB ingot were the 2\#, 3\#, and 4\# slags $[10,19]$.

\subsection{The Viscosity of the Proper Slags}

The mass of the precipitates during the solidification were calculated by using the Equilib mode in Factsage 7.3 (database melts) and the calculated results are shown in Figure 8.

In Figure 8, the total mass of crystallization phase of $\mathrm{CaF}_{2}$ generally kept steady for the three slags. The total mass of crystallization phases of $\mathrm{MgAl}_{2} \mathrm{O}_{4}, \mathrm{Ca}_{3} \mathrm{~B}_{2} \mathrm{O}_{6}$, and $\mathrm{Ca}_{11} \mathrm{~B}_{2} \mathrm{Si}_{4} \mathrm{O}_{22}$ increased, whereas the total mass of crystallization phases of $\mathrm{Ca}_{12} \mathrm{Al}_{14} \mathrm{~F}_{2} \mathrm{O}_{32}$ and $\mathrm{MgO}$ decreased with the increasing $\mathrm{B}_{2} \mathrm{O}_{3}$ and $\mathrm{SiO}_{2}$ addition. The $\mathrm{MgO}$ did not precipitate in the 4\# slag.

According to the calculated results by using the Equilib and Viscosity modes in Factsage 7.3, the calculated modified viscosity of the proper slags versus temperature using Equation (4) are shown in Figure 9.

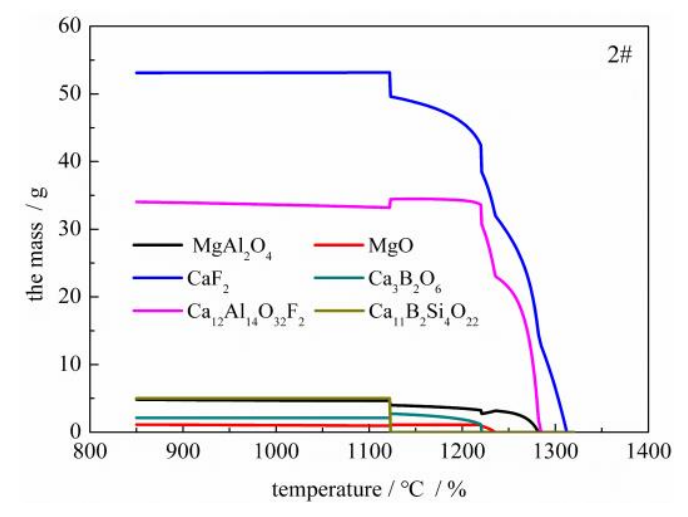

(a)

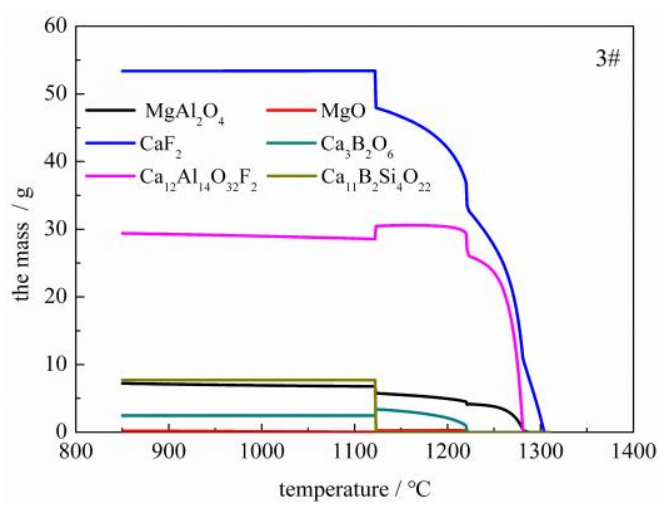

(b)

Figure 8. Cont. 


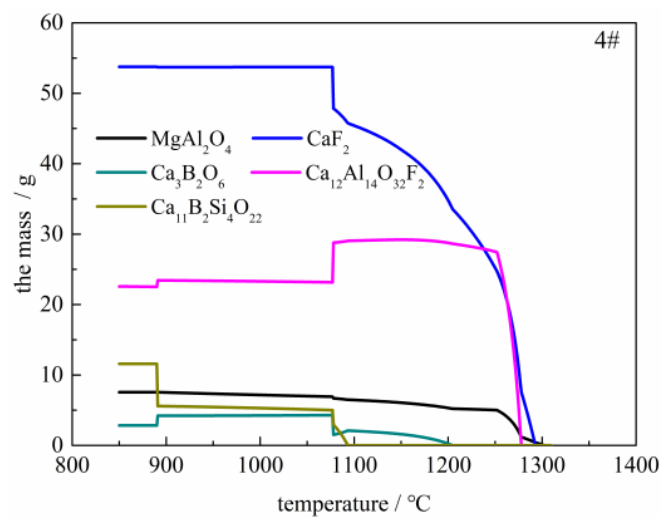

(c)

Figure 8. The mass of the precipitates of the proper slags calculated by Factsage 7.3: (a) 2\# slag; (b) 3\# slag; (c) 4\# slag.

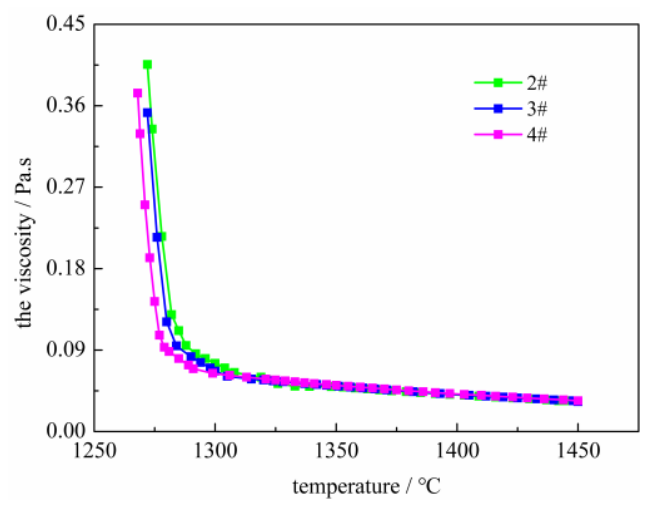

Figure 9. The calculated viscosity of the proper slags versus temperature.

In Figure 9, when the temperature $\geq 1300{ }^{\circ} \mathrm{C}$ the viscosity of the three proper slags were similar, and the viscosity changed slightly with temperature changing, which was beneficial to attain the good surface quality of ingot during ESR process.

\subsection{Laboratory-Scale ESR Experiments}

The viscosity of the three proper slags were all suitable for ESR remelting $9 \mathrm{CrMoCoB}$ ingot, and the ingots remelted under the simple protective gas using the $2 \#, 3 \#$, and $4 \#$ slag are shown in Figure 10a-c, respectively. The surface quality of the three ingots was good. During the ESR process, the concentration of $\mathrm{O}_{2}$ ranged from $0.4 \%$ to $0.6 \%$ (volume fraction).

The vertical distributions of $\mathrm{B}, \mathrm{Si}$, and $\mathrm{Al}$ contents in the three ESR ingots are shown in Figure 11, respectively.

As shown in Figure 11, the B content in the ingots remelted using the 2\# and 3\# slags was $\sim 0.01 \%$, whereas the B content in the ingot remelted using the 4 \# slag was $\sim 0.0095 \%$ with a slight loss. The $\mathrm{Al}$ content $(\leq 0.006 \%)$ in the ingots remelted using the $2 \# \sim 4 \#$ slags kept steady and all was within the target range. The Si content in the ingot remelted using the $2 \#$ slag decreased first, and then became steady at $\sim 0.022 \%$. The loss of $\mathrm{Si}$ in the ingot remelted using the $2 \#$ slag maybe caused by the reaction between $\mathrm{Si}$ and the oxidation products of $\mathrm{FeO}$ during the remelting process. During the laboratory-scale ESR process, the oxygen in the atmosphere permeated into the molten slag pool or the electrode was oxidized by the $\mathrm{O}_{2}$ in the atmosphere, which increased the $\mathrm{FeO}$ content in the molten slag pool. The $\mathrm{Si}$ content in the ingots remelted using the $3 \#$ slag and $4 \#$ slag decreased first, then quickly kept steady around $0.036 \%$ and $0.038 \%$, respectively (the $\mathrm{SiO}_{2}$ content in the molten slag pool was relatively high, the reaction between $\mathrm{Si}$ and $\mathrm{FeO}$ was inhibited). 


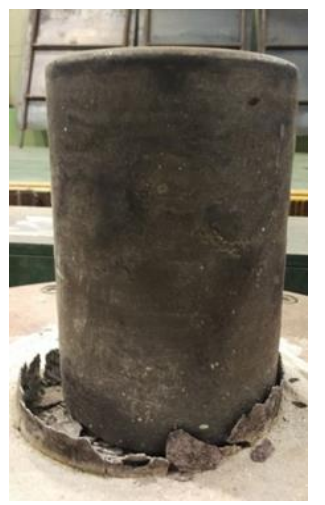

(a)

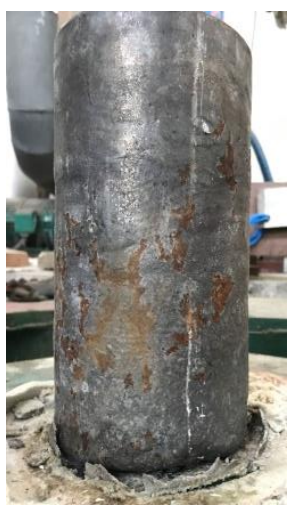

(b)

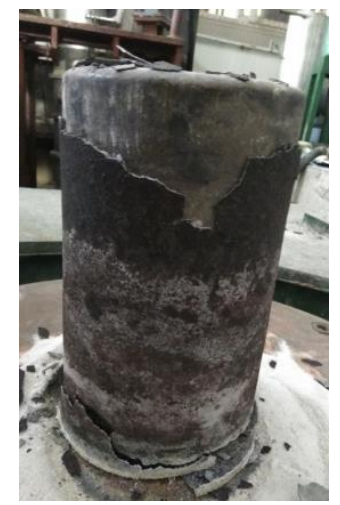

(c)

Figure 10. Ingot remelted by simple protective ESR: (a) 2\# slag; (b) 3\# slag; (c) 4\# slag.

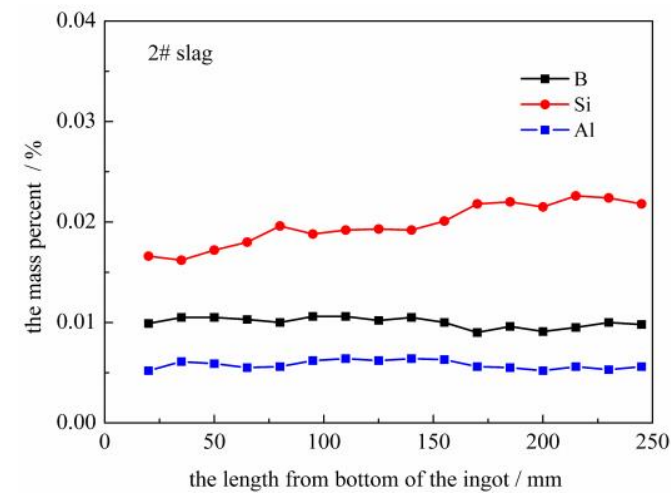

(a)

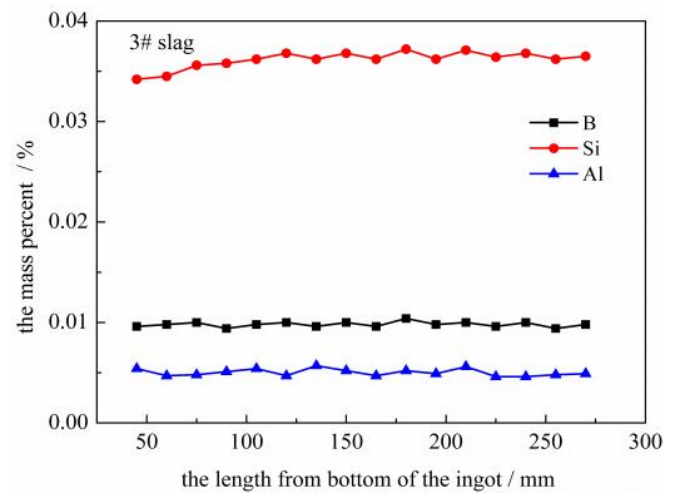

(b)

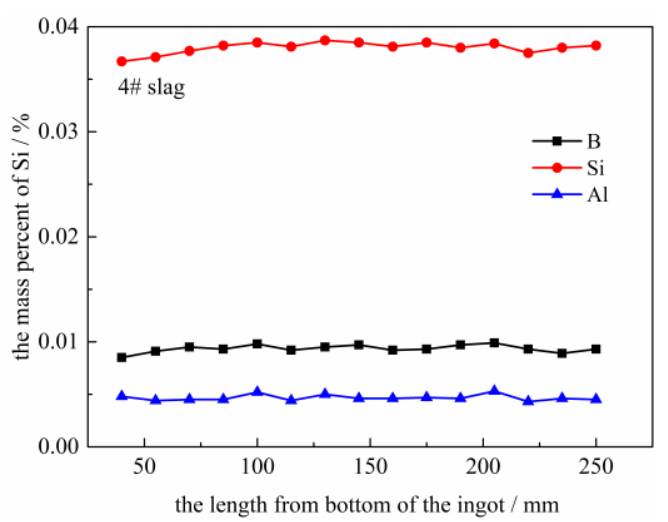

(c)

Figure 11. The distribution of B, Si along the longitude of the ingot remelted by ESR: (a) 2\# slag; (b) 3\# slag; (c) 4\# slag.

According to the laboratory-scale ESR experiments, the B, Si, and Al contents were all within the target range, but the loss and the macro-segregation of $\mathrm{Si}$ in the ingot remelted using the 2\# slag was obvious; therefore, the 2\# slag was not suitable for ESR remelting 9CrMoCoB steel under the laboratory-scale ESR experiment conditions. The Si content decreased in the ingots remelted using the 3\# and 4\# slags first, but the Si content kept steady soon.

The appropriate slags for ESR remelting $9 \mathrm{CrMoCoB}$ steel were the $3 \#$ slag of $55 \% \mathrm{CaF}_{2}-20 \% \mathrm{CaO}-$ $22 \% \mathrm{Al}_{2} \mathrm{O}_{3}-3 \% \mathrm{MgO}-2 \% \mathrm{SiO}_{2}-1.3 \% \mathrm{~B}_{2} \mathrm{O}_{3}$ and the 4 \# slag of $55 \% \mathrm{CaF}_{2}-20 \% \mathrm{CaO}-22 \% \mathrm{Al}_{2} \mathrm{O}_{3}-3 \% \mathrm{MgO}-$ $3 \% \mathrm{SiO}-1.7 \% \mathrm{~B}_{2} \mathrm{O}_{3}$ under the simple protective Ar gas. 


\section{Conclusions}

The principal conclusions conducted from this study are summarized as follows.

(1) The liquid phase region of $\mathrm{CaF}_{2}-\mathrm{CaO}-\mathrm{Al}_{2} \mathrm{O}_{3}-x \% \mathrm{MgO}(0 \leq x \leq 5)$ at $1300 \sim 1400{ }^{\circ} \mathrm{C}$ with the $\mathrm{MgO}$ addition, increased first, then, decreased.

(2) With the increasing $\mathrm{B}_{2} \mathrm{O}_{3}$ content, the equilibrium boron content increased, whereas the equilibrium $\mathrm{Si}, \mathrm{Al}$ contents decreased simultaneously, and, at a given $\mathrm{B}_{2} \mathrm{O}_{3}$ addition, the equilibrium $\mathrm{B}, \mathrm{Al}$ contents decreased, whereas the equilibrium $\mathrm{Si}$ content increased concurrently with increasing $\mathrm{SiO}_{2}$ content.

(3) On the whole, the Factsage calculation results were similar to the experimental results under the same experimental conditions.

(4) The designed slags of $55 \% \mathrm{CaF}_{2}-20 \% \mathrm{CaO}-22 \% \mathrm{Al}_{2} \mathrm{O}_{3}-3 \% \mathrm{MgO}-0 \% \mathrm{SiO}_{2}-0.5 \% \mathrm{~B}_{2} \mathrm{O}_{3}$ and $55 \% \mathrm{CaF}_{2}-20 \% \mathrm{CaO}-22 \% \mathrm{Al}_{2} \mathrm{O}_{3}-3 \% \mathrm{MgO}-1 \% \mathrm{SiO}_{2}-1 \% \mathrm{~B}_{2} \mathrm{O}_{3}$ were not suitable for remelting qualified $9 \mathrm{CrMoCoB}$ ingot for the obvious loss and macro-segregation of $\mathrm{Si}$.

(5) The slags of $55 \% \mathrm{CaF}_{2}-20 \% \mathrm{CaO}-22 \% \mathrm{Al}_{2} \mathrm{O}_{3}-3 \% \mathrm{MgO}-2 \% \mathrm{SiO}_{2}-1.3 \% \mathrm{~B}_{2} \mathrm{O}_{3}$ and $55 \% \mathrm{CaF}_{2}-20 \% \mathrm{CaO}-$ $22 \% \mathrm{Al}_{2} \mathrm{O}_{3}-3 \% \mathrm{MgO}-3 \% \mathrm{SiO}_{2}-1.7 \% \mathrm{~B}_{2} \mathrm{O}_{3}$ were appropriate for ESR remelting qualified $9 \mathrm{CrMoCoB}$ ingot under the simple protective Ar gas (volume fraction of $\mathrm{O}_{2}$ was around $0.5 \%$ ) with controlling the $\mathrm{B}, \mathrm{Si}$, and $\mathrm{Al}$ contents within the target range and avoiding the macrosegregation of $\mathrm{Si}$.

Author Contributions: X.G. and Z.J. conceived and designed the experiments; L.P. performed the experiments; L.P. contributed to writing and editing of the manuscript.

Funding: The authors gratefully acknowledge the support from the National Key R \& D Program of China (Grant No. 2016YFB0300203), which has made this research possible.

Conflicts of Interest: The authors declare no conflicts of interest.

\section{References}

1. Viswanatha, R.; Coleman, K.; Rao, U. Materials for ultra-supercritical coal-fired power plant boilers. Int. J. Pres. Ves. Pip. 2006, 11,778-783. [CrossRef]

2. Viswanathan, R.; Henry, J.F.; Tanzosh, J.; Stanko, G.; Shingledecker, J.; Vitalis, B.; Purgert, R. US program on materials technology for ultra-supercritical coal power plants. J. Mater. Eng. Perform. 2005, 3, 281-292. [CrossRef]

3. Blaes, N.; Donth, B.; Bokelmann, D. High chromium steel forgings for steam turbines at elevated temperatures. Energy Mater. 2007, 4, 207-213. [CrossRef]

4. Masuyama, F. History of power plants and progress in heat resistant steels. ISIJ Int. 2001, 6, $612-625$. [CrossRef]

5. Zeiler, G.; Bauer, R.; Putschoegl, A. Experiences in manufacturing of forgings for power generation application. Metall. Ital. 2010, 6, 33-40.

6. Blaes, N.; Donth, B.; Diwo, A.; Bokelmann, D. Rotor Forgings for Steam Turbines with High Efficiency. In Advances in Materials Technology for Fossil Power Plants, Proceedings of the 7th International Conference, Geauga, OH, USA, 28 September-1 October 2014; Gandy, D., Shingledecker, J., Gandy, D., Shingledecker, J., Eds.; ASM International: Geauga, OH, USA, 2014; pp. 448-458. ISBN 139781627080606.

7. Kim, D.S.; Lee, G.J.; Lee, M.B.; Hur, J.I.; Lee, J.W. Manufacturing of 9CrMoCoB Steel of Large Ingot with Homogeneity by ESR Process. In IOP Conference Series: Materials Science and Engineering; IOP Publishing: Bristol, UK, 2016; Volume 143, p. 012002.

8. Minh, N.Q.; King, T.B. The contribution of electrochemical reactions to sulfur transfer from electrode to slag in electroslag remelting. Metall. Trans. B 1979, 10, 623-629. [CrossRef]

9. Li, S.J.; Cheng, G.G.; Yang, L.; Chen, L.; Yan, Q.Z.; Li, C.W. A Thermodynamic model to design the equilibrium slag compositions during electroslag remelting process: Description and verification. ISIJ Int. 2017, 57, 713-722. [CrossRef]

10. Pateisky, G.; Biele, H.; Fleischer, H.J. The Reactions of Titanium and Silicon with $\mathrm{Al}_{2} \mathrm{O}_{3}-\mathrm{CaO}-\mathrm{CaF}{ }_{2}$ Slags in the ESR Process. J. Vac. Sci. Technol. 1972, 9, 1318-1321. [CrossRef] 
11. Medina, S.F.; Cores, A. Thermodynamic aspects in the manufacturing of microalloyed steels by the electroslag remelting process. ISIJ Int. 1993, 33, 1244-1251. [CrossRef]

12. Reyes-Carmona, F.; Mitchell, A. Deoxidation of ESR slags. ISIJ Int. 1992, 32, 529-537. [CrossRef]

13. Mitchell, A. The chemistry of ESR slags. Can. Metall. Q. 1981, 20, 101-112. [CrossRef]

14. Mohanasundaram, M.; Roy, G.G.; Prakash, S. Thermodynamic Modelling for Design of Synthetic Slag for Inclusion Remova. Trans. Indian Inst. Met. 2019, 72, 1111-1118. [CrossRef]

15. Ren, Y.; Zhang, Y.; Zhang, L. A kinetic model for Ca treatment of Al-killed steels using FactSage macro processing. Ironmak. Steelmak. 2017, 44, 497-504. [CrossRef]

16. Ai, X.B.; Bai, H.; Zhao, L.H.; Cang, D.Q.; Tang, Q. Thermodynamic analysis and formula optimization of steel slag-based ceramic materials by FACTsage software. Int. J. Miner. Metall. Mater. 2013, 20, 379-385. [CrossRef]

17. Presoly, P.; Korp, J.; Schneider, R. Electrical conductivity and corresponding specific energy consumption of new MgO-containing ESR-slags. Arch. Metall. Mater. 2008, 53, 567-574.

18. Dong, Y.W.; Jiang, Z.H.; Cao, Y.L.; Zhang, H.K.; Shen, H.J. Effect of $\mathrm{MgO}$ and $\mathrm{SiO}_{2}$ on surface tension of fluoride containing slag. J. Cent. South Univ. 2014, 21, 4104-4108. [CrossRef]

19. Duan, S.C.; Shi, X.; Mao, M.T.; Yang, W.S.; Han, S.W.; Guo, H.J.; Guo, J. Investigation of the Oxidation Behaviour of Ti and $\mathrm{Al}$ in Inconel 718 Superalloy During Electroslag Remelting. Sci. Rep. 2018, 8, 5232. [CrossRef]

20. Zhengbang, L. A New Advance Electroslag Metallurgy in the 21th Century. Special Steel 2004, 25, 1-5.

21. Arh, B.; Podgornik, B.; Burja, J. Electroslag remelting: A process overview. Mater. Technol. 2016, 50, 971-979. [CrossRef]

22. Wright, S.; Zhang, L.; Sun, S.; Jahanshahi, S. Viscosity of a $\mathrm{CaO}-\mathrm{MgO}-\mathrm{Al}_{2} \mathrm{O}_{3}-\mathrm{SiO}_{2}$ melt containing spinel particles at 1646K. Metall. Mater. Trans. B 2000, 31, 97-104. [CrossRef]

23. Roscoe, R. The viscosity of suspensions of rigid spheres. Br. J. Appl. Phys. 1952, 3, 267-269. [CrossRef]

24. Wright, S.; Zhang, L.; Sun, S.; Jahanshahi, S. Viscosity of calcium ferrite slags and calcium alumino-silicate slags containing spinel particles. J. Non-Cryst. Solids 2001, 282, 15-23. [CrossRef]

(C) 2019 by the authors. Licensee MDPI, Basel, Switzerland. This article is an open access article distributed under the terms and conditions of the Creative Commons Attribution (CC BY) license (http://creativecommons.org/licenses/by/4.0/). 